Review Article

\title{
Impact of Social Distancing on Curtailing COVID 2019 Epidemic in India: A Systematic Review by SWOT Analysis Approach
}

\author{
Sanjeev Davey', Anuradha Davey ${ }^{2}$, Rajesh Jain ${ }^{3}$ \\ ${ }^{1}$ Professor, Community Medicine, Muzaffarnagar Medical College, Muzaffarnagar, Uttar Pradesh. \\ ${ }^{2}$ Associate Professor, Department of Community Medicine, Subharti Medical College, Meerut, Uttar Pradesh. \\ ${ }^{3}$ Medical Director, Jain Hospital Kanpur, Uttar Pradesh.
}

DOI: https://doi.org/10.24321/2455.7048.202009

\section{I $\quad \mathbf{N} \quad \mathbf{F} \quad \mathbf{O}$}

\section{Corresponding Author:}

Sanjeev Davey, Community Medicine, Muzaffarnagar Medical College, Muzaffarnagar, Uttar Pradesh.

E-mail Id:

sanjeevdavey333@gmail.com

Orcid Id:

https://orcid.org/0000-0002-1062-4322

How to cite this article:

Davey S, Davey A, Jain R. Impact of Social Distancing on Curtailing COVID 2019 Epidemic in India: A Systematic Review by SWOT Analysis Approach. Epidem Int 2020; 5(1): 44-49.

Date of Submission: 2020-04-0

Date of Acceptance: 2020-04-13

\section{$\begin{array}{llllllllllllll}\text { A } & \text { B } & \mathbf{S} & \mathbf{T} & \mathbf{R} & \mathbf{A} & \mathbf{C} & \mathbf{T}\end{array}$}

The critical analysis of Impact of Social Distancing as a Public Health Measure to curtail India's Stage 3 of COVID-2019 epidemic carries a crucial importance. Our SWOT analysis reveals that despite being a Good strategy, lack of its strict implementation due to many failures on part of public such as carelessness during many Religious meetings and migrants travel is possibly shifting us into e Stage 3 of Community Transmission of epidemic among many states, of India which is a cause a great worry for Indian Community Existence in World.

Keywords: Physical, Social Distancing, COVID-2019, Epidemic, Pandemic, India, Severe Acute Respiratory Infection, WHO

\section{Introduction}

The COVID 2019 infections, in India till $2^{\text {nd }}$ April 2020 had 1764 active cases, with 15 cured/discharged and 50 deaths. As per few reports of Govt of India and rest of the world, most people around $80 \%$ recover from this disease without needing special treatment. Nearly $16.3 \%$ people who gets COVID-19 become seriously ill and develops serious difficulty in breathing. Although the risk of catching COVID-19 from someone with no symptoms at all is low. But, many people with COVID-19 experience only mild symptoms. This is particularly true at the early stages of the disease. It is therefore possible to catch COVID-19 infection from patient with a mild cough and does not feel ill. ${ }^{1}$
Social distancing, is a non-pharmaceutical public health intervention taken to prevent the spread of a contagious disease by maintaining a physical distance of at least 1 meter between people and reducing the number of times people come into close contact with each other. ${ }^{1-4}$ The principle behind social distancing is to decrease the basic reproduction number, (RO), which is the average number of secondary infected individuals generated from one primary infected individual in a population where all individuals are equally susceptible to a disease. In a basic model of social distancing, ${ }^{1-5}$ where a proportion $f$ of the population engage- in social distancing to decrease their interpersonal contacts to a fraction $\alpha$ of their normal contacts, the new 
effective reproduction number $(R)$ is given by following formula as available from few studies:1-6

$R=\left[1-\left(1-\alpha^{2}\right) f\right] F 0$

From Concepts of epidemiology, the basic goal of social distancing is to decrease the basic reproduction number(R0), and when the value of $\mathrm{R}$ is below 1 - sufficiently long, containment is achieved, and the number infected will decrease.Currently, the reproductive number of the novel coronavirus in developed countries such as US range from 1.4 to 6.5 , with an average of $3.3 .{ }^{6}$ For example, if $25 \%$ ofpopulation reduce their social contacts to $50 \%$ of their normal level this gives an effective reproduction number about $81 \%$ of the basic reproduction number. This small reduction can have a profound effect in delaying the exponential growth and spread of a disease.

It has been seen from study ${ }^{6}$ of Glass R J et al that for influenza infections in year 1957-58 Asian flu $(\approx 50 \%$ infected), closing schools and keeping children and teenagers at home reduced the attack rate by $>$ than $90 \%$. For more infectious strains, the work environment can be targeted. To mitigate a COVID 2019 infectivity similar to that of the 1918-19 Spanish influenza pandemic, simulations suggest that all young and adults must also be targeted regardless of the likely enhanced transmission by the young.

Another study ${ }^{7}$ by Reluga TC (2010) reveals that the key parameters in the epidemic containment analysis are the basic reproduction number and the baseline efficiency of social distancing. The social distancing is most beneficial to individuals with basic reproduction number (R0) 2 . However in the absence of vaccination or other intervention measures, optimal social distancing never recovers not $>$ than $30 \%$ of the cost of infection. The benefits is that the window of opportunity for vaccine development lengthens as the efficiency of social distancing and detection improves.

Social distancing is particularly useful in settings where community transmission is believed to be occuring, and where the linkages between cases are unclear, and where restrictions are placed only on persons known to have been exposed is considered insufficient to prevent further transmission. ${ }^{8}$

Another research, conducted by the COV-IND-19 Study Group in which analysis was done based on the coronavirus outbreak models of Hubei, China. This study has revealed that India may witness nearly 13 lakh cases by mid-May, if the spread of the virus is not contained. However, the experts claim that the number of cases may change if testing, stringent measures and restrictions are implemented. ${ }^{9}$ Recent studies have shown that asymptomatic can be as infectious as the patient with symptoms. Therefore, there is a need to track post-travel symptoms among people..$^{1-6}$

\section{Role of Physical (Social) Distancing in Flattening Epidemic Curve}

As per the CDC Report, many collective protective actions such as Hand hygeine, Social Distancing, and Cleaning Surfaces can limit the spread of COVID 2019 Infections in Community. Social distancing is one of the most important factors by which the COVID-19 outbreak can be controlled. By reducing the probability that a given uninfected person will come into physical contact with an infected person, the disease transmission can be suppressed, resulting in less deaths. The social distancing must are combined with good respiratory hygiene and hand washing and use of face masks tp prevent Community Spread of Infection. ${ }^{6,10}$ In the currentthe 2019-2020 coronavirus pandemic, the World Health Organization (WHO) suggested more stress towards adoption of "physical" distancing as an alternative to "social", in keeping with the notion that it is a physical distance which prevents transmission; people can remain socially connected via technology. ${ }^{11}$ So Physical distancing is such an important containment measure.

\section{Material \& Methods}

\section{The Systematic Review Strategy}

PRISMA (Preferred Reporting Items for Systematic Reviews and Meta-Analyses) is an evidence-based minimum set of items aimed at helping authors to report a wide array of systematic reviews and meta-analyses.

\section{Systematic Review Strategy: PRISMA (2009 Guidelines)}

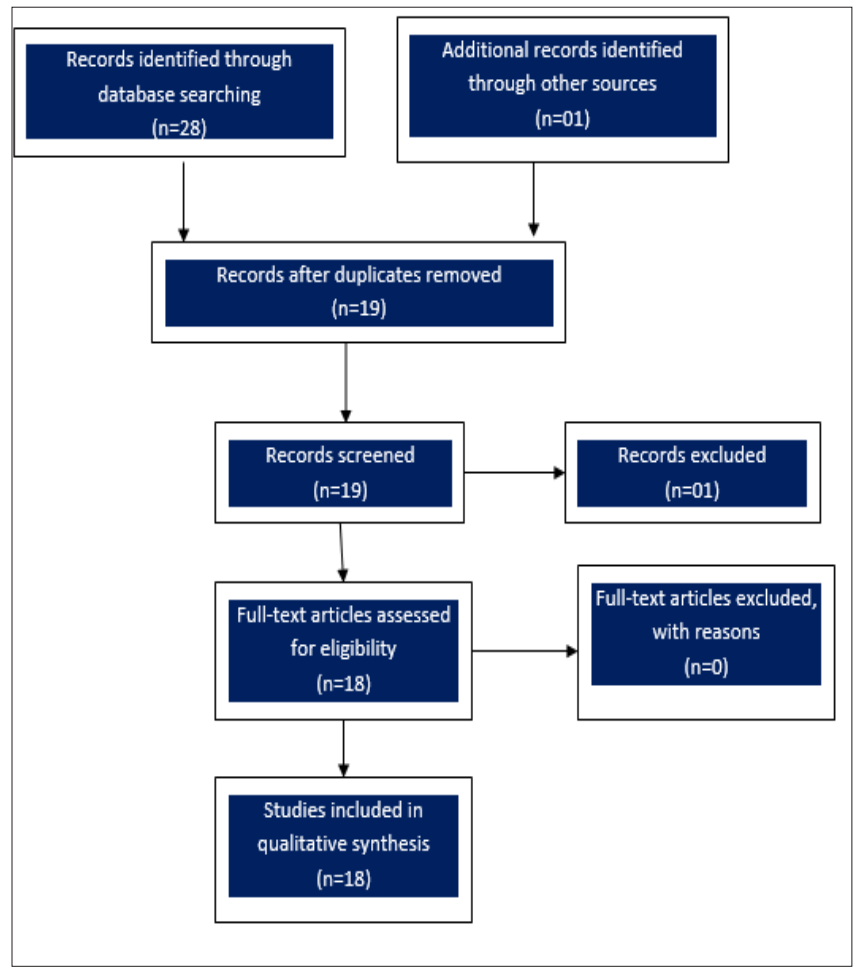




\section{Result}

Table I.Synthesis of themes from Key studies in systematic-reviewa

\begin{tabular}{|c|c|c|c|c|c|c|c|}
\hline $\begin{array}{l}0 \\
z \\
\text { vi }\end{array}$ & $\begin{array}{l}\text { Name of } \\
\text { author of } \\
\text { study with } \\
\text { reference } \\
\text { citation }\end{array}$ & 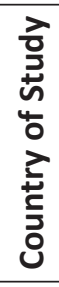 & 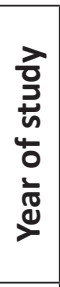 & $\begin{array}{c}\text { Study } \\
\text { methodology } \\
\text {-study } \\
\text { design, } \\
\text { sample size } \\
\text { etc } \\
\end{array}$ & Key findings & Implications of studies & $\begin{array}{c}\text { Issues } \\
\text { synthesized } \\
\text { from studies }\end{array}$ \\
\hline -i & $\begin{array}{l}\text { Katie } \\
\text { Pearce }\end{array}$ & 弚 & 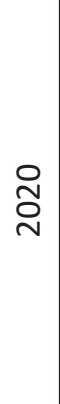 & $\begin{array}{l}\text { John Hopkins } \\
\text { University } \\
\text { Website } \\
\text { Information }\end{array}$ & Social Distancing & $\begin{array}{l}\text { Social distancing slows } \\
\text { down the outbreak in } \\
\text { order to reduce the } \\
\text { chance of infection } \\
\text { among high-risk } \\
\text { populations and to } \\
\text { reduce the burden on } \\
\text { health care systems and } \\
\text { workers }\end{array}$ & $\begin{array}{l}\text { Individual } \\
\text { behavior } \\
\text { changes are } \\
\text { even more } \\
\text { important. } \\
\text { Individual } \\
\text { actions are } \\
\text { humble but } \\
\text { powerful }\end{array}$ \\
\hline$i$ & 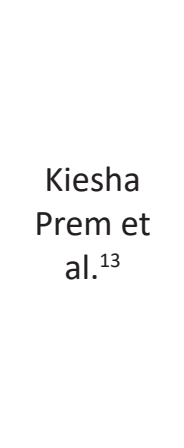 & 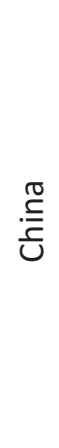 & 尽 & $\begin{array}{l}\text { Research } \\
\text { article }\end{array}$ & $\begin{array}{l}\text { effect of control } \\
\text { strategies to reduce } \\
\text { social mixing on } \\
\text { outcomes of the } \\
\text { COVID-19 Epidemic }\end{array}$ & $\begin{array}{l}\text { Non pharmaceutical } \\
\text { interventions based } \\
\text { on sustained physical } \\
\text { distancing have a } \\
\text { strong potential to } \\
\text { reduce the magnitude } \\
\text { of the epidemic peak } \\
\text { of COVID-19 and lead } \\
\text { to a smaller number of } \\
\text { overall cases. }\end{array}$ & $\begin{array}{l}\text { Lowering and } \\
\text { flattening of the } \\
\text { epidemic peak } \\
\text { is particularly } \\
\text { important, as } \\
\text { this reduces the } \\
\text { acute pressure } \\
\text { on the health- } \\
\text { care system. }\end{array}$ \\
\hline$\dot{m}$ & $\begin{array}{l}\text { Adhikari } \\
\text { SP et al. }{ }^{14}\end{array}$ & 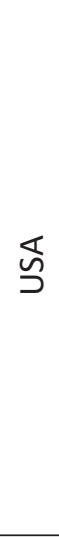 & ণ্ণ & $\begin{array}{l}\text { Scoping } \\
\text { Review }\end{array}$ & $\begin{array}{l}\text { Most of the } \\
\text { publications were } \\
\text { written using the } \\
\text { English language } \\
\text { (89.2\%). The largest } \\
\text { proportion of } \\
\text { published articles } \\
\text { were related to } \\
\text { causes ( } 38.5 \%) \text { and } \\
\text { a majority (67.7\%) } \\
\text { were published by } \\
\text { Chinese scholars }\end{array}$ & $\begin{array}{l}\text { Preventive measures } \\
\text { such as masks, hand } \\
\text { hygiene practices, } \\
\text { avoidance of public } \\
\text { contact, case detection, } \\
\text { contact tracing, and } \\
\text { quarantines have been } \\
\text { discussed as ways to } \\
\text { reduce transmission. }\end{array}$ & $\begin{array}{l}\text { infected people } \\
\text { primarily rely } \\
\text { on symptomatic } \\
\text { treatment and } \\
\text { supportive care } \\
\text { and avoiding } \\
\text { public contact. }\end{array}$ \\
\hline$\dot{+}$ & $\begin{array}{l}\text { Chen, W } \\
\text { et al. }{ }^{15}\end{array}$ & $\stackrel{\frac{\pi}{5}}{\frac{.}{U}}$ & 尽 & $\begin{array}{l}\text { Descrpitive } \\
\text { study }\end{array}$ & $\begin{array}{l}\text { In the early stages of } \\
\text { the epidemic, China } \\
\text { adopted the } \\
\text { containment strategy } \\
\text { and implemented a } \\
\text { series of core } \\
\text { measures around this } \\
\text { strategic point }\end{array}$ & $\begin{array}{l}\text { Strengthening case } \\
\text { isolation and close } \\
\text { contacts tracking } \\
\text { management, blocking } \\
\text { epidemic areas and } \\
\text { traffic control to reduce } \\
\text { personnel movements }\end{array}$ & $\begin{array}{l}\text { increase social } \\
\text { distance, } \\
\text { environmental } \\
\text { measures } \\
\text { and personal } \\
\text { protection, }\end{array}$ \\
\hline ம் & Qualls N. ${ }^{16}$ & 弚 & 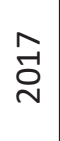 & $\begin{array}{l}\text { Descriptive } \\
\text { study }\end{array}$ & $\begin{array}{l}\text { Impact of many } \\
\text { Public health } \\
\text { interventions }\end{array}$ & $\begin{array}{l}\text { Strict Following of } \\
\text { Social Distancing }\end{array}$ & $\begin{array}{l}\text { Social Distancing } \\
\text { is Critical. }\end{array}$ \\
\hline
\end{tabular}


The 4 key themes which emerged from this systematic review were:

All 4 themes which emegerged highlighted the SWOT Analysis of Social Distancing [ Table no :01].

- Theme 01: Strenghths of Social Distancing in Reducing COVID 2019 Epidemic.

- Theme 02: Weaknesses in Implementation of Social Distancing.

- Theme 03: Opportunities Gained and Lost in Social Distancing.

\section{Discussion}

There is presently no treatment for COVID 2019 infection across the world except few suggestive treatments of use of Hydroxy-Chloroquine, Azithromycin and Antiretovirals drugs used in Indian Scenario, but Significant results in all patients of COVID 2019 Infections are questionable. The mini review study of Singhal T India (2020) has also stressed that treatment of this disease is supportive and Prevention strategy must focus on home isolation of suspected cases and those with mild illnesses and strict infection control measures at hospitals that include contact and droplet precautions and adoption of Social Distancing measures for Community.

\section{Theme 0I: Strenghths of Social Distancing in Reducing COVID 2019 Epidemic}

Many studies (Katie Pearce, ${ }^{12}$ Kiesha Prem et al., ${ }^{13}$ Adhikari $\mathrm{SP},{ }^{14}$ Chen, $\mathrm{W}$ et al. $)^{15}$ have revealed many benefits of Social Distancing in curtailing the epidemic. As per the John Hopkins University Website Information (Pearce K 2020) ${ }^{12}$ it appears that although Social distancing although it can reduce the chance of infection among high-risk populations, but Individual behaviour changes are more important. Another study by Kiesha Prem et al also revealed that there is a positive effect of control strategies to reduce social mixing on outcomes of the COVID-19 Epidemic.

Another study of Adhikari SP et al. ${ }^{14}$ also focuses on many Preventive measures apart from, avoidance of public contact, as ways to reduce transmission and similar opinions were also came out from study of Chen, W et al. ${ }^{15}$ where increase social distance was emphasized in the early stages of the epidemic, as China also adopted the same containment strategy.

\section{Theme 02: Weaknesses in Implementation of Social Distancing}

The study of Qualls N (2017) et al. ${ }^{16}$ reveals that the scale and disruptive impact of many Public health interventions were small compared with the measures that were implemented in China in response to COVID-19, electronic surveillance. ${ }^{6}$ The effectiveness and societal impact of quarantine and social distancing will depend on the credibility of public health authorities, political leaders and institutions. It is important that policy makers maintain the public's trust through use of evidence-based interventions and fully transparent, fact-based communication. ${ }^{6}$ The only weakness with this is that the possible high compliance with non-elderly social distancing is needed to contain the peak of Epidemic. Moreover, immediate social distancing, focused on the elderly population (esp $>65$ years) is also very critical with at least 3-4 week period of complete isolation for the elderly. The longer this period, the more we can delay infections into Community for at least 3 months. The societal impact of quarantine and social distancing actually depends on the evidence-based interventions of the health authorities and policymakers. Though social distancing can do a lot to slow the spread of diseases like Covid-19, it has not yet been able to stop it completely. ${ }^{12}$

In one Indian study (Singh R \& Adhikari R 2003) ${ }^{17}$ on the impact of social distancing measures - A 3 -week lockdown was found insufficient to prevent a resurgence and, instead, protocols of sustained lockdown with periodic relaxation are suggested and at least 49 days Lockdown in India is all that desired. However, under the pessimistic scenario (RO is 4.9) expected by ICMR, the projected impact in terms of reducing cases would be just 2 per cent, which is the most likely scenario we may achieve and we can reduce the overall number of cases by $62 \%$ and the peak number of cases by $89 \%$ in India and flatten the curve. ${ }^{3}$

\section{Theme 03: Opportunities Gained and Lost in Social Distancing}

According to ICMR, using mathematical modelling, a study of 8 researchers from the Indian Council of Medical Research and Imperial College, London by experts at ICMR has estimated that India may be able to reduce its Covid-19 cases by up to 62 per cent if social distancing and quarantines are strictly observed. ${ }^{[2]}$ Based on this, for their predictions, researchers in ICMR's study created two scenarios: optimistic scenario (when R0 is 1.5) and pessimistic scenario (when RO is 4.9). These can be understood as the least risky and most risky scenarios.

\section{Theme 04: Threats remaining even after Implementation of Social Distancing}

Social or physical distancing is considered very critical in slowing or reducing the transmission of the virus. Studies reveal that even people without symptoms can spread the virus, some infected individuals who have not shown symptoms can spread the virus and this remains an issue of great concern. Even Modelling studies in China and Japan, and testing of those on the Diamond Princess cruise ship suggest that a small number of people who are infected do not develop symptoms. We don't know much about how infectious these asymptomatic individuals might be, that is, how likely they are to spread the disease. 
As per many media reports in TV Channels and Newspapers in the Month of March 2020 that many religious meetings were held before and during Nationwide LOCKDOWN and sudden stoppage of all factories in India especially Delhi has caused all the Migrant workers to leave via any mode of transport and this has most probably spread the Infection from Delhi to all over India jeopardizing our aim of Social (Physical Distancing). This may become the most probable cause of Spread of Infection from Local Transmission mode to stage 3 Community as appearing from many studies also. ${ }^{14-21}$

\section{Conclusion}

The societal impact of social distancing depends on the evidence-based interventions of the health authorities and policymakers. Despite the best advantages of Social Distancing and being a very Good strategy, lack of its strict implementation due to many failures on part of public such as carelessness during many Religious meetings and migrants travel and the ineffective following of it by public on seious basis, does not appear to be properply materialized in Indian community even during Nationwide lockdown by Govt of India. This may drift us into the stage 3 of Community Transmission of COVID 2019 Infection in India

\section{Conflicts of Interest: None \\ References}

1. COVID 2019. Questions \& Answers on COVID 2019 for Public. Available from: https://www.mohfw.gov.in/[ Last updated 2020, Apr 4 \& last Cited 2020 Apr apr 4].

2. Margaret $H$, Ghebreyesus A, Tedros Liu, Tu Ryan, Michael M J, Vadia et al. COVID-19" (PDF). World Health Organization. Archived (PDF) from the original on 202003-25. Retrieved 2020-03-29. A [ Last updated 2020, March 25 \& last Cited 2020 March 29]. 2020.

3. Hensley, Laura. Social distancing is out, physical distancing is in - here's how to do it. Global News. Corus Entertainment Inc. Archived from the original on 202003-27. Retrieved 2020-03-29. [ Last updated 2020, March 25 \& last Cited 2020 March 29]. 2020.

4. Venske, Regula. Schwyzer, Andrea (ed.). "Die Wirkung von Sprache in Krisenzeiten" [The effect of language in times of crisis] (Interview). NDR Kultur (in German). Norddeutscher Rundfunk. Archived from the original on 2020-03-27. Retrieved 2020-03-27. [Last updated 2020, March 25 \& last Cited 2020 March 29] 2020.

5. Johnson CY, Sun L, Freedman A. Social distancing could buy U.S. valuable time against coronavirus: It's a makeor-break moment with coronavirus to test one of the most basic - but disruptive - public health tools. The Washington Post. Archived from the original on 2020; 03-27.
6. Why Experts Are Urging Social Distancing to Combat Coronavirus Outbreak. Available from: csf.edu/ news/2020/03/416906/why-experts-are-urging-socialdistancing-combat-coronavirus-outbreak[ Last updated 2020, Apr 4 \& last Cited 2020 Apr apr 4].

7. Becker N. Modeling to Inform Infectious Disease Control. CRC Press 2015; 104. ISBN 978-1-49873107-2.

8. Glass RJ, Glass LM, Beyeler WE, Min HJ. Targeted social distancing design for pandemic influenza. Emerg Infect Dis. 2006; 12(11): 1671-1681.

9. Reluga TC. Game theory of social distancing in response to an epidemic. PLoS Comput Biol 2010; 6(5): e1000793.

10. Smith WA, Freedman DO. Isolation, quarantine, social distancing and community containment: pivotal role for old-style public health measures in the novel coronavirus (2019-nCoV) outbreak. Journal of Travel Medicine 2020; 27.

11. Projections warn 13 Lakh COVID 2019 Cases. Available from: https://weather.com/en-IN/india/coronavirus/ news/2020-03-30-projections-warn-13-lakh-covidcases-india-icmr-social-distancing[ Last updated 2020, Apr 4 \& last Cited 2020 Apr apr 4].

12. Pearce K. What Is Social Distancing And How An It Slow The Spread Of Covid-19?Available from : https://hub. jhu.edu/2020/03/13/what-is-social-distancing/[ Last updated 2020, Apr 4 \& last Cited 2020 Apr apr 4].

13. Prem K, Liu Y, Russell TW, Kucharski AJ, Eggo RM, Davies $\mathrm{N}$. The effect of control strategies to reduce social mixing on outcomes of the COVID-19 epidemic in Wuhan, China: a modelling study. Lancet Public Health 2020; 25. pii: S2468-2667(20)30073-6.. [Epub ahead of print].

14. Adhikari SP, Meng S, Wu YJ, Mao YP, Ye RX, Wang QZ et al. Epidemiology, causes, clinical manifestation and diagnosis, prevention and control of coronavirus disease (COVID-19) during the early outbreak period: a scoping review. Infect Dis Poverty 2020; 9(1): 29.

15. Chen W, Wang Q, Li Y, Q Yu, H L, Xia YY et al .Early containment strategies and core measures for prevention and control of novel coronavirus pneumonia in China. Chinese journal of preventive medicine 2020; 54. 1-6. 10.3760/cma.j.issn.0253-9624.2020.03.003.

16. Qualls N, Levitt A, Kanade N et al. CDC Community Mitigation Guidelines Work Group. Community mitigation guidelines to prevent pandemic influenzaUnited States, 2017. MMWR Recomm Rep 2017;66(No. $\mathrm{RR}$ ).

17. Singh R, Adhikari R. Age-structured impact of social distancing on the COVID-19 epidemic in India. Quantitative biology arXiv: 2003.12055v1 [q-bio. $\mathrm{PE}$ ] 26.18.Why social distancing is key in containing the new coronavirus. Available from: https://www. medicalnewstoday.com/articles/why-social-distancing- 
is-key-in-containing-the-new-coronavirus. [Last updated 2020, Apr 4 \& last Cited 2020 Apr apr 4].

18. Rothe et al. Transmission of 2019-nCoV Infection from an Asymptomatic Contact in Germany, NEJM 2020.

19. Why social distancing is key in containing the new coronavirus. Available from: https://www.medical newstoday.com/articles/why-social-distancing-is-keyin-containing-the-new-coronavirus [Last updated 2020, Apr 4 \& last Cited 2020 Apr apr 4].

20. Singhal T. A Review of Coronavirus Disease-2019 (COVID-19). Indian J Pediatr 2020; 87(4): 281-286.

21. Jernigan DB. Update: Public Health Response to the Coronavirus Disease 2019 Outbreak - United States, February 24, 2020. MMWR Morb Mortal Wkly Rep 2020; 69(8): 216-219. 